\title{
PERBANDINGAN PEMBERIAN BEBERAPA LEVEL MIKROKAPSUL MINYAK IKAN DALAM RANSUM TERHADAP PERFORMA BROILER
}

\author{
Toni Malvin ${ }^{1}$ \\ E- mail : tonimalvin@yahoo.co.id
}

\begin{abstract}
This study aimed to determine the effect of fish oil microcapsules (MMI) in feed on broiler performance. The research material is 80 head of broiler DOC and basal feed with $22 \%$ protein and energy metabolism of $3000 \mathrm{Kcal} / \mathrm{kg}$. The research method was conducted using completely randomized design (CRD) with 4 treatments and 5 replications. The first treatment $(R A)$ is a feed containing $0.8 \%$ fish oil (control), the second treatment $(R B)$ containing $2 \% M M I$, the third (RC) containing 4\% MMI, and the fourth (RD) containing 6\% MMI. Variables measured: feed consumption, body weight gain, feed conversion, and carcass percentage. Results of analysis of variance showed that the use of fish oil microcapsules to level 6\% in broiler feed gives different effects are not noticeable for feed consumption and carcass percentage. As for the body weight gain and feed conversion ratio, the treatment gave a significantly different effect. From this study it can be concluded that the use of MMI (microencapsulated fish oil) with a level of $2 \%$ was more effective in improving body weight gain and decrease the feed conversion ratio of broiler compared with controls (unprotected fish oil).
\end{abstract}

Keywords: broiler, chicken, microencapsulated fish oil, performance.

\section{PENDAHULUAN}

Bagi masyarakat Indonesia, ternak ayam merupakan sumber protein hewani penting, hal ini disebabkan karena ternak ayam, khususnya broiler merupakan salah satu komoditas peternakan yang dalam waktu yang relatif singkat dapat menghasilkan daging dan dengan harga yang relatif terjangkau. Seiring dengan hal tersebut, pemahaman kesehatan pangan di masyarakat juga ikut berkembang, sehingga pola konsumsi terus mengalami peningkatan untuk memperoleh daging yang berkualitas, untuk itu perlu dilakukan upaya dalam menghasilkan produk daging tersebut, yang salah satunya dapat ditempuh dengan cara memanipulasi pakan/ransum.

Pada umumnya, bahan penyusun ransum unggas terdiri dari $70 \%$ sumber energi dan $25 \%$ sumber protein. Salah satu bahan pakan sumber energi yang ketersediaannya cukup melimpah dan mengandung asam lemak essensial yang dibutuhkan oleh tubuh adalah minyak ikan lemuru. Minyak ikan lemuru dapat dimanfaatkan dalam ransum broiler untuk memenuhi kebutuhan 
energi yang tinggi yang tidak mengarah pada pembentukan kadar lemak dan kolesterol pada daging broiler (Rusmana, 2008). Pemanfaatan minyak ikan sebagai salah satu bahan pakan ayam juga mempunyai peranan penting dalam meningkatkan sumberdaya manusia dan pencegahan penyakit modern, karena minyak ikan banyak mengandung asam lemak omega-3. Asam lemak omega-3 mampu mencegah penyakit kardiovaskuler serta meningkatkan perkembangan fungsi otak dan retina mata pada bayi (Nettleton, 2005).

Pemberian minyak ikan secara langsung ke dalam ransum broiler mengalami beberapa kendala, diantaranya pakan lebih cepat tengik karena minyak ikan tersebut sangat mudah teroksidasi. Disamping itu, minyak ikan dalam bentuk cair kurang praktis penggunaannya ke dalam ransum, karena sering terjadinya penggumpalan yang menyebabkan ransum tidak homogen, sehingga perlu dicari upaya untuk mengatasinya. Salah satu cara yang dapat ditempuh untuk mengatasi hal tersebut adalah dengan cara pemberian minyak ikan dalam bentuk mikrokapsul.

Mikrokapsul Minyak Ikan (MMI) diperoleh dengan cara memerangkap minyak ikan dengan bahan penyalut dan selanjutnya dikeringkan dengan pengering semprot. Proses tersebut disebut juga dengan mikroenkapsulasi. Hasil dari mikroenkapsulasi tersebut diperoleh MMI yang berbentuk tepung dengan kandungan ME dan protein kasar masing-masing sebesar 3691 Kkal dan 31,50\% (Montesqrit dan Adrizal, 2008).

Sejauh ini, pemberian minyak ikan dalam bentuk mikrokapsul belum banyak dilaporkan, khususnya pada ternak broiler. Berdasarkan uraian diatas, perlu dilakukan penelitian tentang penggunaan mikrokapsul minyak ikan terhadap performa broiler yang meliputi : konsumsi ransum, pertambahan bobot badan, konversi ransum, persentase karkas, dan persentase lemak abdomen. Penelitian ini bertujuan untuk memberikan informasi tentang pengaruh pemberian beberapa level mikrokapsul minyak ikan dalam ransum terhadap performa broiler.

\section{METODE PENELITIAN}

Ternak yang digunakan pada penelitian ini adalah 80 ekor DOC broiler kelamin jantan dan betina umur 2 (dua) hari yang diperoleh dari PT. Charoen Pokphand Indonesia Tbk. Ransum yang digunakan merupakan ransum basal dengan kadar protein 22\% dan kandungan energi 3000 
$\mathrm{Kkal} / \mathrm{kg}$. Bahan-bahan penyusun ransum terdiri dari dedak halus, jagung giling, bungkil kedelai, tepung ikan, minyak kelapa, minyak ikan, mikrokapsul minyak ikan, topmix dan tepung batu.

Minyak ikan yang digunakan diperoleh dari hasil sampingan pengolahan tepung ikan dari Muncar, Banyuwangi. Bahan penyalut yang digunakan untuk pembuatan mikrokapsul minyak ikan adalah tepung daging dan bungkil kelapa yang masing-masing terdiri dari $77 \%$ dan 23\% (Montesqrit dan Adrizal, 2008). Kandang yang digunakan adalah kandang panggung yang diberi alas litter (sekam padi) dan disekat-sekat sebanyak 20 unit dengan ukuran $0.5 \mathrm{~m}$ x $1 \mathrm{~m}$ perunit, yang masing-masing diisi 4 ekor ayam.

Metode penelitian ini dilakukan menurut Rancangan Acak Lengkap (RAL) dengan 4 perlakuan dan 5 ulangan, dimana tiap unit kandang ditempati oleh 4 ekor ayam sebagai unit percobaan. Sebagai perlakuan adalah penggunaan Mikrokapsul Minyak Ikan (MMI) yang terdiri dari :

- Perlakuan RA : Ransum mengandung Minyak Ikan 0,8\% (kontrol)

- Perlakuan RB : Ransum mengandung MMI 2\% ( 0,4\% Minyak Ikan)

- Perlakuan RC : Ransum mengandung MMI 4\% ( 0,8\% Minyak Ikan)

- Perlakuan RD : Ransum mengandung MMI 6\% ( 1,2\% Minyak Ikan)

\section{HASIL DAN PEMBAHASAN}

\section{Nilai Gizi Ransum}

Nilai gizi ransum dilihat dari kandungan protein kasar (PK), lemak, serat kasar (SK), calsium $(\mathrm{Ca})$, posfor $(\mathrm{P})$ dan energi metabolis $(\mathrm{ME})$ seperti tertera pada Tabel 1.

Tabel 1. Nilai gizi ransum penelitian dengan berbagai level mikrokapsul minyak ikan.

\begin{tabular}{lcccc}
\hline \multirow{2}{*}{ Nilai Gizi } & \multicolumn{4}{c}{ Ransum Perlakuan } \\
\cline { 2 - 5 } & RA & RB & RC & RD \\
\hline PK (\%) & 22,02 & 22,00 & 22,01 & 22,02 \\
Lemak (\%) & 2,54 & 3,00 & 3,49 & 3,98 \\
SK (\%) & 3,61 & 3,51 & 3,59 & 3,67 \\
Ca (\%) & 0,96 & 1,02 & 1,07 & 1,11 \\
P (\%) & 0,40 & 0,42 & 0,42 & 0,43 \\
ME (Kkal/kg) & 2927,20 & 2999,50 & 3000,30 & 2999,50 \\
\hline
\end{tabular}

Keterangan : $\mathrm{RA}=$ Ransum $\mathrm{A}, \mathrm{RB}=$ Ransum B, RC = Ransum C, RD = Ransum D 


\section{Konsumsi Ransum}

Rataan konsumsi broiler per ekor selama 4 minggu dengan pemberian mikrokapsul minyak ikan dalam ransum dapat dilihat pada tabel 2.

Tabel 2. Rata-rata konsumsi ransum broiler per ekor selama penelitian.

\begin{tabular}{lc}
\hline \multicolumn{1}{c}{ Perlakuan } & Konsumsi (gram) \\
\hline RD (ransum mengandung MMI 6\%) & 1480,0 \\
RA (ransum mengandung minyak ikan 0,8\%) & 1472,0 \\
RC (ransum mengandung MMI 4\%) & 1428,5 \\
RB (ransum mengandung MMI 2\%) & 1425,0 \\
\hline
\end{tabular}

Keterangan : Berbeda tidak nyata $(\mathrm{P}>0,05)$

Berdasarkan hasil analisis ragam, terlihat bahwa pemberian mikrokapsul minyak ikan sampai taraf $6 \%$ ke dalam ransum broiler menunjukkan pengaruh berbeda tidak nyata $(\mathrm{P}>0,05)$ terhadap konsumsi ransum. Kondisi ini menunjukkan bahwa palatabilitas dan kandungan nutrisi ransum yang disediakan dalam penelitian ini adalah sama, sehingga tidak mempengaruhi konsumsi ransum dari broiler. Hal ini juga menandakan bahwa mikrokapsul minyak ikan yang ditambahkan stabil, karena kadar air dari mikrokapsul tersebut rendah sehingga tidak mudah tengik dan tidak menurunkan palatabilitas dari ransum.

Pada penelitian ini, pemberian mikrokapsul minyak ikan tidak merubah kandungan energi dari ransum, karena ransum disusun secara isoprotein dan isokalori, sehingga konsumsi ransum relatif sama atau berbeda tidak nyata $(\mathrm{P}>0,05)$ pada semua perlakuan. Hal ini sesuai dengan pendapat NRC (1994) yang menyatakan bahwa, faktor utama yang mempengaruhi konsumsi ransum pada unggas adalah nilai energi ransum yang diberikan. Ayam akan berhenti mengkonsumsi ransum apabila kebutuhan energi sudah terpenuhi. Selanjutnya Kartasudjana dan Suprijatna (2006) juga menyatakan bahwa, ayam mengkonsumsi ransum untuk memenuhi kebutuhan energinya, sebelum kebutuhan energinya terpenuhi ayam akan terus makan. Jika ayam diberi makan dengan kandungan energi rendah maka ayam akan makan lebih banyak.

Konsumsi ransum pada penelitian ini berkisar antara 1425,0 - 1480,0 g/ekor, dimana lebih rendah dibandingkan dengan standar konsumsi ransum yang dikeluarkan oleh PT. Charoen Pokphand Indonesia untuk broiler dengan kode CP 707 yaitu sebesar 1923 g/ekor selama 4 minggu pemeliharaan. Perbedaan konsumsi ransum ini mungkin disebabkan oleh kualitas dan komposisi bahan makanan yang berbeda, sehingga palatabilitas dari ransum juga berbeda. 


\section{Pertambahan Bobot Badan}

Rataan pertambahan bobot badan broiler per ekor selama 4 minggu, dengan pemberian mikrokapsul minyak ikan dalam ransum dapat dilihat pada tabel 3.

Tabel 3. Rata-rata pertambahan bobot badan (PBB) broiler per ekor selama penelitian.

\section{Perlakuan}

RD (ransum mengandung MMI 6\%)

RC (ransum mengandung MMI 4\%)

RB (ransum mengandung MMI 2\%)

RA (ransum mengandung minyak ikan 0,8\%)
PBB (gram)

$1146,50^{\mathrm{b}}$

$1085,50^{\mathrm{b}}$

$1078,00^{\mathrm{b}}$

$988,00^{\mathrm{a}}$

Keterangan : Super skrip dengan huruf kecil yang tidak sama menunjukkan perbedaan yang nyata $(\mathrm{P}<0,05)$

Berdasarkan hasil analisis ragam, terlihat bahwa pemberian perlakuan menunjukkan pengaruh berbeda nyata $(\mathrm{P}<0,05)$ terhadap pertambahan bobot badan. Secara angka-angka terlihat bahwa pertambahan bobot badan cenderung meningkat seiring dengan meningkatnya komposisi mikrokapsul minyak ikan dalam ransum. Hasil ini berbeda dengan penelitian Rusmana (2010) yang menggunakan minyak ikan lemuru sebagai subtitusi dari minyak sawit dalam ransum ayam broiler, dimana hasil penelitian menunjukkan meskipun terdapat pengaruh perlakuan terhadap konsumsi ransum, namun terhadap pertambahan bobot badan tidak menunjukkan perbedaan yang nyata.

Pertambahan bobot badan pada perlakuan RB, RC dan RD lebih tinggi dibanding kontrol, hal ini diduga karena kadar lemak dalam pakan yang lebih tinggi, sehingga meningkatkan ketersediaan dan kecernaan nutrien pakan dalam saluran pencernaan ayam broiler, dan berdampak pada perbaikan kecernaan sehingga PBB yang dihasilkan berbeda. Hal ini sejalan dengan pendapat Wahju (1997) yang menyatakan bahwa penambahan lemak dalam pakan dapat meningkatkan daya cerna pakan dalam usus. Penambahan minyak dalam pakan meningkatkan kandungan lemak muscular dalam daging yang mampu meningkatkan bobot badan ternak ayam broiler tersebut (Soeparno, 2005)

Fadilah et al., (2007) dan Wahju (1997) menyatakan bahwa minyak atau lipida mempunyai peranan yang sangat penting dalam pertumbuhan ayam, dalam hal ini berfungsi sebagai sumber energi, membantu absorpsi vitamin yang larut dalam lemak, mengurangi sifat 
berdebu dalam pakan dan mungkin juga membantu palatabilitas makanan, juga berfungsi sebagai sumber panas.

Pertambahan bobot badan pada penelitian ini berkisar antara 988,00 - 1146,50 g/ekor, dimana sedikit lebih rendah dibandingkan dengan standar pertambahan bobot badan yang dikeluarkan oleh PT. Charoen Pokphand Indonesia untuk broiler dengan kode CP 707 yaitu ratarata sebesar 1215 g/ekor untuk masa pemeliharaan 4 minggu. Perbedaan ini mungkin disebabkan oleh rendahnya konsumsi ransum penelitian jika dibandingkan dengan standar konsumsi ransum yang dicapai oleh PT. Charoen Pokphand Indonesia, serta kualitas dan komposisi bahan makanan yang berbeda, karena setiap protein mempunyai perbedaan dengan protein lain (Siregar et al., 1980).

\section{Konversi Ransum}

Rataan konversi ransum broiler selama 4 minggu dengan pemberian mikrokapsul minyak ikan dalam ransum dapat dilihat pada tabel 4.

Tabel 4. Rata-rata konversi ransum broiler per ekor selama penelitian.

\begin{tabular}{lc}
\multicolumn{1}{c}{ Perlakuan } & Konversi Ransum \\
\hline RD (ransum mengandung MMI 6\%) & $1.30^{\mathrm{b}}$ \\
RC (ransum mengandung MMI 4\%) & $1.32^{\mathrm{b}}$ \\
RB (ransum mengandung MMI 2\%) & $1.33^{\mathrm{b}}$ \\
RA (ransum mengandung minyak ikan 0,8\%) & $1.49^{\mathrm{a}}$
\end{tabular}

Keterangan : Super skrip dengan huruf kecil yang tidak sama menunjukkan perbedaan yang nyata $(\mathrm{P}<0,05)$

Berdasarkan hasil analisis ragam, terlihat bahwa pemberian mikrokapsul minyak ikan menunjukkan pengaruh berbeda sangat nyata $(\mathrm{P}<0,01)$ terhadap konversi ransum. Kondisi ini membuktikan bahwa minyak ikan dalam bentuk mikrokapsul memberikan hasil yang lebih baik dibandingkan pemberian minyak ikan secara langsung (tanpa dilindungi), karena dalam bentuk mikrokapsul, kualitas minyak ikan akan tetap terjaga sehingga penggunaannya lebih efektif dan tepat sasaran, yang pada akhirnya dapat menurunkan rasio dari konversi ransum.

Konversi ransum pada penelitian ini berkisar antara 1,30 - 1,49, dimana lebih rendah dibandingkan dengan standar konversi ransum yang dikeluarkan oleh PT. Charoen Pokphand Indonesia untuk broiler dengan kode CP 707 yaitu rata-rata sebesar 1,52. Hal ini juga 
membuktikan bahwa pemberian mikrokapsul minyak ikan mampu meningkatkan efisiensi pakan broiler.

NRC (1994) melaporkan, broiler yang diberi ransum dengan tingkat energi $3200 \mathrm{kkal} / \mathrm{kg}$ dengan protein $23 \%$ pada umur 0 - 3 minggu dilanjutkan dengan protein $20 \%$ pada umur $3-6$ minggu, konversi ransum yang dicapai adalah 1,81. Sedangkan pada penelitian ini protein yang digunakan berkisar antara 22,00 - 22,02\% dengan tingkat energi 2927,20 - 3000,30 kkal/kg mampu menghasilkan nilai konversi yang lebih rendah, yaitu antara 1,30 - 1,49. Pada penelitian lain yang dilakukan Rusmana (2010), tingkat energi ransum penelitian yang digunakan berkisar 3052 - $3061 \mathrm{kkal} / \mathrm{kg}$ dengan protein ransum 21,46 \% menghasilkan konversi ransum antara 1,84 - 2,22. Menurut Rizal (2006), angka kebutuhan energi yang absolut tidak ada, karena ayam dapat menyesuaikan jumlah ransum yang dikonsumsi dengan kebutuhan energi bagi tubuhnya.

Rendahnya nilai konversi ransum yang diperoleh pada penelitian ini dibandingkan dengan standar dari produsen (PT. Charoen Pokphand Indonesia) maupun dari para peneliti lainnya, merupakan sebuah nilai tambah dalam penggunaan mikrokapsul minyak ikan pada broiler, dimana terlihat bahwa pertumbuhan broiler dalam kondisi baik dengan konsumsi pakan yang lebih hemat.

\section{Persentase Karkas}

Rataan persentase karkas broiler umur 4 minggu dengan pemberian mikrokapsul minyak ikan dalam ransum dapat dilihat pada tabel 5.

Tabel 5. Rata-rata persentase karkas broiler per ekor pada akhir penelitian.

\begin{tabular}{lc}
\hline \multicolumn{1}{c}{ Perlakuan } & Karkas (\%) \\
\hline RB (ransum mengandung MMI 2\%) & 61,99 \\
RD (ransum mengandung MMI 6\%) & 60,52 \\
RC (ransum mengandung MMI 4\%) & 59,13 \\
RA (ransum mengandung minyak ikan 0,8\%) & 58,88 \\
\hline
\end{tabular}

Keterangan : Berbeda tidak nyata $(\mathrm{P}>0,05)$

Berdasarkan hasil analisis ragam, terlihat bahwa pemberian mikrokapsul minyak ikan sampai taraf 6\% ke dalam ransum broiler menunjukkan pengaruh berbeda tidak nyata $(\mathrm{P}>0,05)$ terhadap persentase karkas. Hal ini menunjukkan bahwa pemberian mikrokapsul minyak ikan dalam ransum tidak mampu mengubah persentase karkas broiler secara signifikan. Hal yang 
senada juga dilaporkan oleh Rusmana dkk (2010), dimana pemberian ransum yang mengandung minyak ikan lemuru hingga taraf 6\% dan suplementasi vitamin E hingga 200 ppm tidak menunjukkan perbedaan yang nyata $(\mathrm{P}>0,05)$ terhadap persentase karkas.

Menurut Murtidjo (1992), persentase karkas broiler yang normal berkisar antara $65-75 \%$ dari bobot hidup waktu siap potong. Sedangkan pada penelitian ini persentase karkas yang dihasilkan ternyata lebih rendah, yaitu berkisar antara 58,88 - 61,99\%. Hal ini mungkin disebabkan oleh perbedaan waktu panen dan perbedaan komposisi bahan makanan serta protein tercerna dalam ransum. Namun jika dibandingkan dengan hasil yang diperoleh Sylviani (2011), yakni berkisar antara 58,64 - 65,68\% untuk broiler umur 4 minggu, maka nilai yang dicapai pada penelitian ini masih normal. Sementara pada penelitian lain yang dilakukan Hasanah (2002), yang menggunakan ransum silase ikan-tape ubi kayu dengan perhitungan protein kasar 21,56 21,60 dan energi metabolis 2931,95 - 2964,15 memperoleh rataan berat karkas antara 58,50 65,45\% untuk ayam yang dipanen pada umur 6 minggu, dimana hasilnya juga tidak jauh berbeda dengan hasil yang diperoleh pada penelitian ini.

Menurut Brake dan Havenstein (1993), persentase karkas berhubungan dengan jenis kelamin, umur dan bobot hidup. Karkas meningkat seiring dengan meningkatnya umur dan bobot hidup. Hal yang sama dilaporkan oleh Soeparno (2005) bahwa, persentase karkas meningkat sesuai dengan peningkatan berat hidup, tetapi menurunkan persentase bagian non karkas. Selanjutnya ia juga menyatakan bahwa faktor yang mempengaruhi nilai dan kualitas karkas yaitu: faktor genetik, dalam bangsa ternak yang sama, komposisi karkas dapat berbeda.

\section{KESIMPULAN DAN SARAN}

Berdasarkan hasil penelitian dapat disimpulkan bahwa penggunaan MMI (mikrokapsul minyak ikan) dengan taraf $2 \%$ lebih efektif dalam meningkatkan pertambahan bobot badan dan menurunkan konversi ransum broiler dibandingkan dengan kontrol (minyak ikan yang tidak dilindungi), sedangkan untuk konsumsi ransum dan persentase karkas, memberikan pengaruh berbeda tidak nyata hingga pemakaian MMI taraf $6 \%$. 


\section{DAFTAR PUSTAKA}

[NRC] National Research Council, 1994. Nutrient Requirements of Poultry. Ed ke-9. Washington DC: National Academy Pr Baucells MD. Crespo N. Barroeta SC. LopezFerrer S. Grashorn MA. 2000. Incorporation of different polyunsaturated fatty acids into eggs. Poultry Sci 79:51-59.

Brake, J.G.B. and S.E. Havenstein. 1993. Relationship of Sex. Age and Body Weight to Broiler Carcass Yield and Offal Production. Poultry Sci. 72: 1137-1145.

Fadilah, R., A. Polana, S. Alam. dan E. Parwanto. 2007. Sukses Beternak Ayam Broiler. PT Agromedia Pustaka. Jakarta.

Hasanah, S. 2002. Pengaruh Pemberian Silase Ikan-Tape Ubi Kayu Terhadap Persentase Berat Karkas, Lemak Abdomen dan Orgam Dalam Ayam Broiler. Skripsi. Fakultas Peternakan IPB, Bogor.

Kartasudjana, R. dan Suprijatna. E. 2006. Manajemen Ternak Unggas. Penebar Swadaya. Jakarta.

Montesqrit, dan Adrizal. 2008. Optimasi Produksi Mikrokapsul Minyak Ikan Sebagai Feed Aditif untuk Menghasilkan Produk Unggas Kaya Asam Lemak Omega-3 dan Rendah Kolesterol. Laporan Penelitian Hibah Bersaing. Universitas Andalas. Padang.

Murtidjo, B.A. 1992. Pedoman Beternak Ayam Broiler. Kanisius. Yogyakarta.

Nettleton, J.A. 2005. Omega-3 Fatty Acids in Food and Health. Food Tech. 59:120.

Rizal, Y. 2006. Ilmu Nutrien Unggas. Andalas University Press. Padang

Rusmana, D. 2008. Minyak Ikan Lemuru sebagai Imunomodulator dan Penambahan Vitamin E untuk Meningkatkan Kekebalan Tubuh Ayam Broiler. Disertasi. Program Pascasarjana IPB. Bogor.

Rusmana, D. 2010. Pengaruh Subtitusi Minyak Sawit oleh Minyak Ikan Lemuru dan Suplementasi Vitamin E Dalam Ransum Ayam Broiler Terhadap Performans. http://pustaka.unpad.ac.id/wp-content/uploads/2010/10/

pengaruh_ransum_mengandung_minyak_ikan_lemuru_thdp_bobot_bdh_akhir.pdf. [17-042012].

Rusmana, D., D. Natawiharja. dan Lalah. L.S. 2010. Pengaruh Ransum Mengandung Minyak Ikan Lemuru dan Suplementasi Vitamin E Terhadap Bobot Badan Akhir. Persentase Karkas Dan Lemak Abdominal Ayam Broiler. http://pustaka.unpad.ac.id/wpcontent/uploads/2010/10/ pengaruh_ransum_mengandung_minyak_ikan_lemuru_thdp_bobot_bdh_akhir.pdf [17-042012]. 
Siregar, A.P.M, Sabrani. dan P. Suroprawiro. 1980. Teknik Beternak Ayam Pedaging di Indonesia. Cetakan ke-I. Margie Group. Jakarta.

Soeparno, 2005. Ilmu dan Teknologi Daging. Gadjah Mada University Press. Yogyakarta.

Sylviani, C. 2011. Pengaruh Ampas Sari Kedelai Fermentasi sebagai Pengganti Protein Bungkil Kedelai terhadap Bobot Hidup, Persentase Karkas dan Persentase Lemak Abdomen pada Broiler. Skripsi. Fakultas Peternakan Universitas Andalas, Padang.

Wahju, J. 1997. Ilmu Nutrisi Unggas. Gadjah Mada University Press. Yogyakarta. 